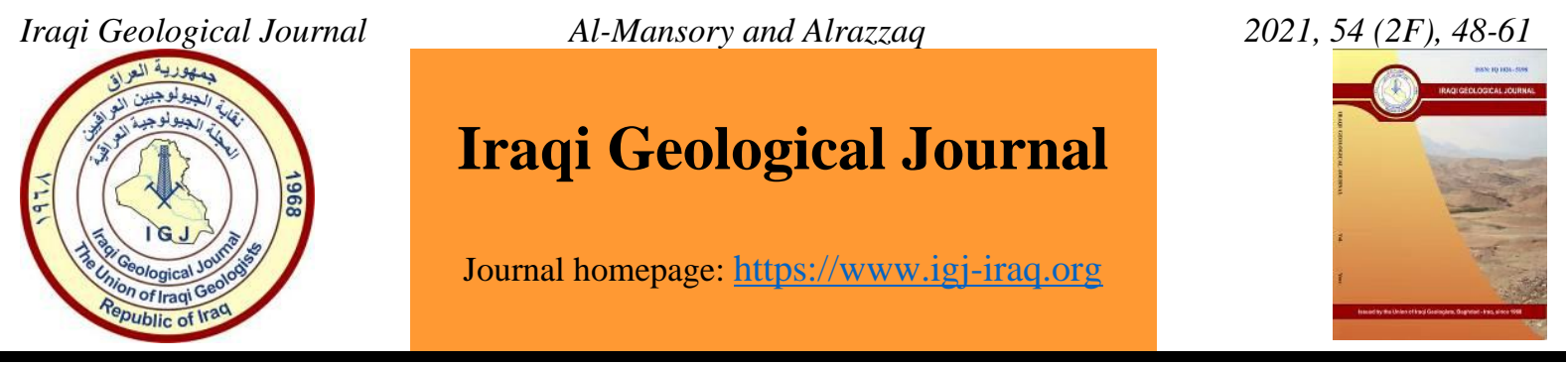

\title{
Determination of Safe Mud Weight Window in Rumaila Oilfield, Southern Iraq
}

\author{
Walaa Khyrie ${ }^{1 * *}$ and Ayad A. Alhaleem A. Alrazzaq ${ }^{1}$ \\ 1 Petroleum Department, College of Engineering, University of Baghdad, Baghdad, Iraq \\ * Correspondence: walaaalmansory91@gmail.com
}

Received: 1 August 2021; Accepted: 15 October 2021; Published: 31 December 2021

\begin{abstract}
The oil and gas industry, wellbore instability plays an important role in financial losses and stops the operations while the drilling which leads to extra time known as non-productive time. In this work, a comprehensive study was carried out to realize the nature of the instability problems of the wellbore in Rumaila oilfield to improve the well design. The study goal is to develop a geomechanical model in one dimension by utilizing Schlumberger Techlog (Version 2015) software. Open hole wireline measurements were needed to develop the model. The model calibrating and validating with core laboratory tests (triaxial test), well test (Mini-frac test), repeated formation test. Mohr-Coulomb, Mogi-Coulomb, and Modified Lade are the three failure criteria which utilized to analyze the borehole breakouts and to determine the minimum mud weight needed for a stable wellbore wall. For more accuracy of the geomechanical model, the predicted profile of the borehole instability is compared with the actual failure of the borehole that is recorded by caliper log. The results of the analysis showed that the MogiCoulomb criteria are closer to the true well failure compared with the other two criteria and considered as the better criteria in predicting the rock failure in the Rumaila oilfield. The wellbore instability analysis revealed that the vertical and low deviated wells (less than $40^{\circ}$ ) is safer and more stable. While, the horizontal and directional wells should be drilled longitudinally to the direction of the minimum horizontal stresses at a range between $140^{\circ}-150^{\circ}$ North West-South East and the mud weight recommended is increased to 10.5 ppg to avoid most of instabilities problems. The results contribute in development plan of the wells nearby the studied area and decreasing NPT and cost.
\end{abstract}

Keywords: Geomechanical model; Safe mud weight window; Mogi-Coulomb criteria

\section{Introduction}

In spite of utilizing new technique in oil and gas industry, wellbore instability is still the major and more challenge during the drilling practice and production through increasing the non-productive time (NPT) and over cost of well (Abbas et al., 2019). Cost estimation range about 10-20\% for treatment the instabilities problems of the wellbore from the total cost of drilling. An annual economic loss in petroleum industry range between 1-6 \$ billion cross the world because of the problems of the wellbore instability (Albukhari et al., 2018). Over $85 \%$ of instabilities problems occur in shaly formations and about $75 \%$ of all formation which drill in petroleum industry (Abbas et al., 2018). Shaly formations in Southern Iraqi oilfield include Tanuma, Nahr-Umr, Ahmadi, and Zubair Upper Shale (Al-Mimar et al., 2021; Awadh et al., 2018; Awadh et al., 2021). The Zubair Formation is the most productive reservoir

DOI: $10.46717 /$ igj.54.2F.5ms-2021-12-22 
in Iraq and the surrounding countries and composed of shale and sandstone with streaks of siltstone and limestone (Al Jafar et al., 2019). These formations are considered as more problematic formations while drilling processes (Alsultan et al., 2021; Awadh et al., 2021). Two major types caused wellbore instability which are tensile and/or shear failure (Aadnoy and Looyeh, 2011). If the operating mud pressure is less than the breakout pressure will cause failure in the borehole and flow of formation fluid to the wellbore which is known-as (Kick). While, if the mud pressure is greater than the breakdown pressure, which causes losses of the drilling fluid to the formation that will impact of the rock permeability (Rasouli et al., 2011). Wellbore instability can take different shapes such as enlargement of the borehole its known- as caving, reduction hole size (tight hole), lost circulation, and stuck pipe subsequently fishing operations (Zhang, 2013). Analysis of the wellbore instability is an important step in the future plan of drilling new wells and in the field development through design of the safe mud weight window and optimize the trajectories of the wells. To achieve this purpose, develop a geomechanical model involving pore pressure, in-situ horizontal stresses (magnitude and orientation), overburden stress (vertical stress), and rock mechanical properties. The estimation of the mechanical properties of the rock is necessary issues in each application related to the geomechanics and the rock properties including the rock mechanical and petrophysical properties have been measured in the laboratory including the unconfined compressive strength, Young's modulus, passions ratio, tensile strength and friction angle (Aziz et al., 2021). In geomechanical model utilized different failure criteria to predict the rock failure and determine the limits of mud pressure. Thus, the basic aspect of the instability in the wellbore by choosing the most appropriate failure criteria. The most common failure criteria Mohr-Coulomb criteria but is overrate in calculation of limits of mud pressure which needed for safe drilling due to Mohr criteria ignore the impact of the intermediate stress. while the intermediate strength plays a main role in supply extra strengthening to the rock (Haimson and chang, 2000). Many problems occur when using Mohr-Coulomb criteria and because of these troubles, Al-Ajmi and Zimmerman (2005) introduced a new type of criterion known-as Mogi-Coulomb criterion. This failure criterion dose not ignoring the intermediate stress and that gives more realistic results. This study aims to develop a geomechanical model for Rumaila oilfield to understanding and discussing the source and nature of the problems that might be faced while drilling practice and apply the results for future plan of drilling a new well without drilling issues.

\section{Study Area}

Rumaila oilfield was discovered in 1953 and is considered as one of the greatest oilfields around the world, so known-as the supergiant field. It is located about $50 \mathrm{~km}$ to west Basrah, Southern Iraq. Rumaila encompasses an area of $1,600 \mathrm{~km}^{2}$ and approximately expanding $80 \mathrm{~km}$ north to south towards border of Iraqi-Kuwait, and $20 \mathrm{~km}$ west to east towards of West-Qurna oilfield (Fig.1). It is consisting of the two anticlines which are North dome and South dome. Rumaila reservoir including the carbonate and stacked sandstone lies up to $4 \mathrm{~km}$ and belongs to the Cretaceous age (ROO, 2016; Mimar et al., 2021; Awadh et al., 2018; Awadh et al., 2021).).

\section{Materials and Methods}

Dataset of vertical well are examined for predicting the majority of the instability of wellbore problems which take place during shaly formations. These data included final well report, well test like extended leak-off test (X-LOT) or mini-frac test, daily drilling report, mud log report, geological report, laboratory core test report and measurements of the open hole wireline logging (gamma ray, caliper, density, sonic shear and compression $\log$ ). The method of detecting and reducing the instability problems in the wellbore is including developed a geomechanical model by using software programs Schlumberger Techlog (Version 2015) Software. 


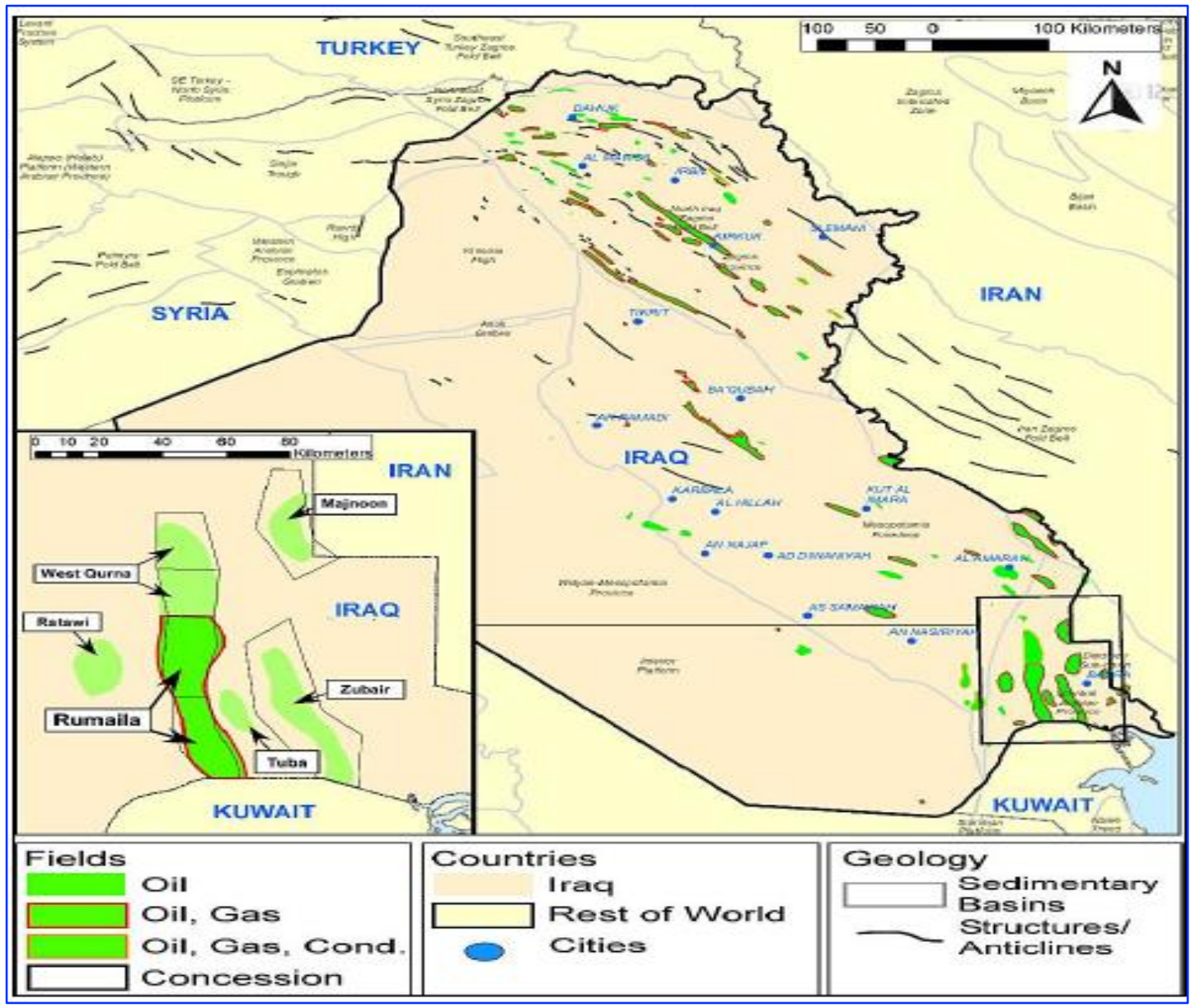

Fig.1. Location map of Rumaila oilfield (ROO, 2016)

The methodology involved the following steps and illustrated in (Fig.2):

- Determine the overburden (vertical) stress based on the density log and compute the profile of the pore pressure from density and sonic compressional log.

- Compute the rock mechanical parameters which involved the elastic and strength properties from sonic (shear and compressional) log and validating the measured values with the laboratory core results.

- Determine the magnitude of the minimum and maximum horizontal stress from static elastic parameters, vertical stress, and pore pressure, then calibrated with the results of extend leak-off test point.

- Point $(1,2,3)$ represent to the input parameters of geomechanical model.

- Identify the orientation of the horizontal stresses from the oriented caliper log of the wellbore and/ or from the formation micro-image log (FMI).

- Compare the predicted failure of wellbore that is determined by using different failure criterion with the actual profile of the wellbore that records by caliper $\log$ in order to validate the geomechanical model.

- Implement the sensitivity analysis at single depth to find the stable mud weight window and safe orientation (inclination and azimuth) to the nearby regions to drill new wells. 


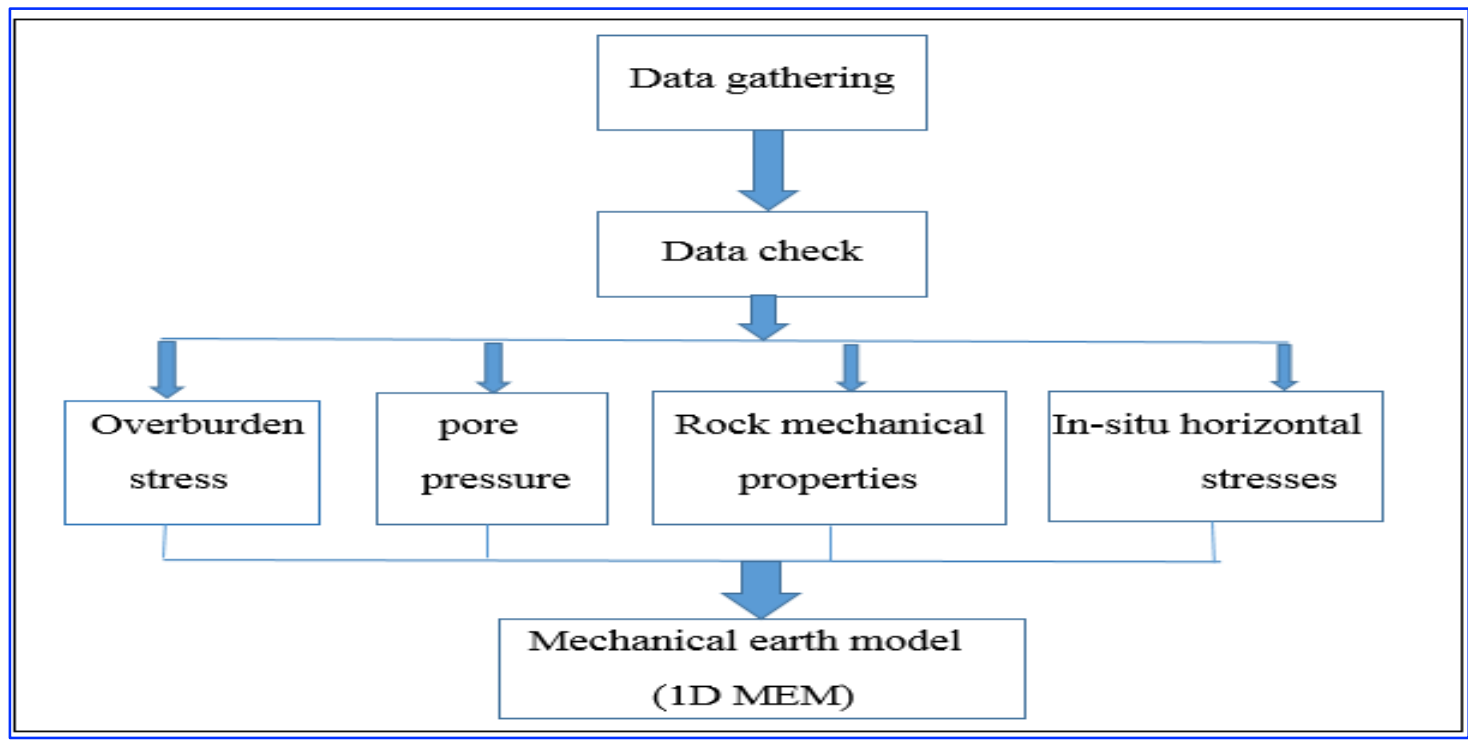

Fig. 2. Workflow of geomechanical model (1-D-MEM)

\section{Geomechanical Modeling}

\subsection{Overburden Stress Magnitude}

At a given depth, the overburden (vertical) stress is defined as the pressure exerted by the overlying weight of the sediments with the fluid that it contains (Schlumberger, 2015). It is one of the main input elements to each analysis of the mechanical earth model. The extrapolated density method which used to evaluate the value of the overburden stress by integrating the bulk density $\log$ (RHOB) that is covered from Sadi Formation to the lower of Zubair Formation by using equation (1) (Aadnoy \& Looyeh, 2011).

$$
S v=\int_{0}^{z} \rho g(\mathrm{z}) \mathrm{dz}
$$

Where:

$S v$ : vertical stress (psi).

$\rho$ : bulk density of the rocks as a function of depth $\left(\mathrm{gm} / \mathrm{cm}^{3}\right)$.

g: gravitational acceleration $\left(\mathrm{m} / \mathrm{s}^{2}\right)$.

Z: formation depth (m).

While, the intervals which is not covered with density log can be estimated by using equation (2) (Schlumberger, 2015).

Where:

$$
\text { extapolated }=\text { emudline }+ \text { Ao } \times(\text { TVD }- \text { Air Gap })^{\alpha}
$$

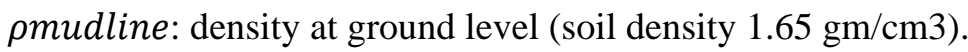

Air Gap: rig floor height from the ground level (m).

TVD: true vertical depth (m).

Ao and $\alpha$ : fitting parameters.

\subsection{Pore Pressure}

Pore pressure also termed as formation pressure is an important component in mechanical earth modeling and critical parameter in the calculations of determining the horizontal principal stresses and analysis of the borehole stability. The accurate pore pressure prediction impact on the successful of the drilling operations (Zhang, 2019). The pore pressure profile was computed by combining of the normal and geo-pressures profiles. The profile of normal pore pressure (Hydrostatic pressure) was calculated by used equation (3) (Bjorlykke, 2010) by depended on an average formation water density for Rumaila 
oilfield of $1.09(\mathrm{gm} / \mathrm{cm} 3)$. Eaton (1975) method was depended to estimate the profile of geo-pressure that which derived based on the measurement of slowness as formulated in equation (4) (Najibi et al., 2017). The calculated value of pore pressure which validated with the direct measurement of formation pressure that obtained from RFT that measured in Mishrif, Nahr-Umr and Zubair formations and showed an acceptable agreement. Eaton slowness dose not predicted the depleted regions therefore the deviated between RFT measurements and pore pressure is sensible.

$$
\begin{aligned}
& \text { Phydrostatic }=\int_{0}^{\mathrm{z}} \rho w \mathrm{~g} \mathrm{dz} \\
& \quad P p g=O B G-(O B G-\mathrm{P} p n)\left(\frac{\mathrm{NCT}}{\mathrm{DT}}\right)^{3}
\end{aligned}
$$

Where:

Ppg: Pore pressure gradient.

OBG: Overburden gradient.

Ppn: Hydrostatic pressure gradient.

NCT: Normal compacted trend line that is fitting to the compressional wave log measurements.

DT: Compressional transit time.

\subsection{Rock Mechanical Properties}

The main mechanical properties of the rock including elastic properties (Poisson's ratio (V) and Young's modulus (E)) and strength features (unconfined compressive strength (UCS), friction angle $(\varphi)$, and tensile strength (To)). These properties are an important and essential to make a comprehensive study of wellbore instability analysis, determination of stresses, and prediction of an appropriate mud weight for safe drilling process. The direct method (laboratory test) to measure the rock mechanical properties is more accurate and commonly that utilized to validate the calculated profiles of rock properties which estimated by indirect methods (depended on well logging data). Sonic model was utilized to compute the dynamic moduli from sonic log (shear and compressional) and bulk density log to estimate the dynamic shear (Gdyn) and bulk (Kdyn) moduli as formulated in equation (5) and (6) that was required to calculate of Young's modulus and Poisson's ratio as a function of bulk and shear moduli by using equation 7 and 8 respectively (Fjaer et al., 2008; Schlumberger, 2015).

$$
\begin{gathered}
\text { Gdyn }=13474.45 \frac{\rho b}{\Delta \text { shear }^{2}} \\
\text { Kdyn }=13474.45\left(\frac{1}{\Delta \text { tcomp }^{2}}\right)-\frac{4}{3} \text { Gdyn }
\end{gathered}
$$

Where:

Gdyn: shear modulus in (Mpsi).

Kdyn: bulk modulus in (Mpsi).

$\rho \mathrm{b}$ : formation bulk density from density $\log$ in $\left(\mathrm{gm} / \mathrm{cm}^{3}\right)$.

$\Delta$ tcomp and $\Delta$ tshear: compressional and shear acoustic travel time in $(\mu \mathrm{sec} / \mathrm{ft})$.

$$
\begin{gathered}
E=\frac{9 K * G}{G+3 K} \\
V=\frac{3 K-2 G}{6 K+2 G}
\end{gathered}
$$

Where:

$\mathrm{V}$ : Poisson's ratio (unitless).

E: Young's modulus in (Mpsi). 
As for the strength mechanical properties, the unconfined compressive strength (UCS) profile was estimated based on static Young's modulus correlations. The profile of the internal friction angle was estimated by utilizing Maps Gamma-ray correlation to internal friction angle with a linear relation as shown in (Fig.3). Finally, the profile of tensile strength was determined based on UCS (Schlumberger, 2015). The estimated profile of the mechanical properties of the rock was calibrated with the direct measurements of laboratory core test results and showed an acceptable agreement as shown in (Fig.5).

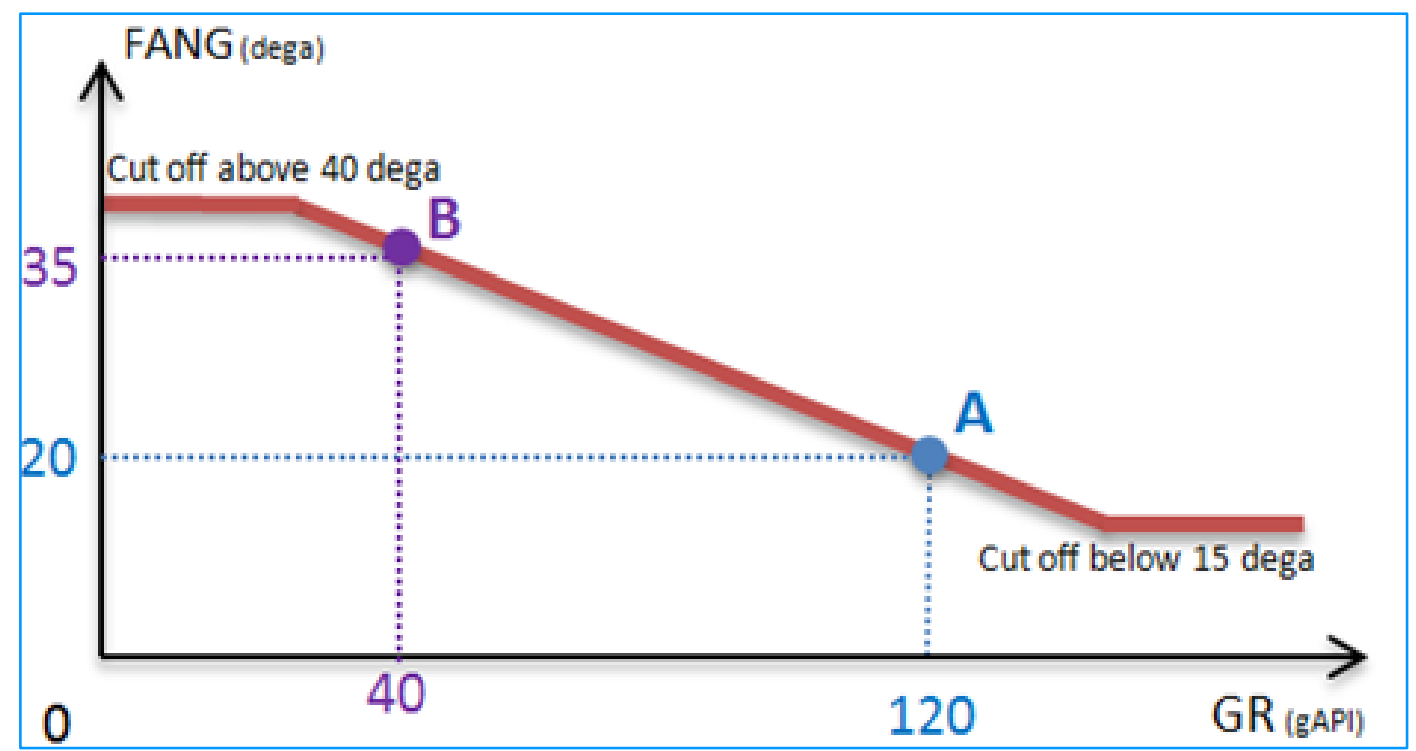

Fig. 3. Friction angle from Gamma-ray log (Schlumberger, 2015).

\subsection{Horizontal Stress Magnitudes and Orientations}

The magnitude of the minimum and maximum horizontal stresses considered as a major and fundamental input parameter for each developing of geomechanical model and computing the rock failure. There is only one direct method to measure the magnitude of minimum horizontal stress such as Mini-frac test, leak-off test, and extend leak-off test, whereas no direct method to determine the magnitude of the maximum horizontal stress. While, there are various indirect method to determine the magnitude of the in-situ horizontal stress depended on well logging data (Zhang, 2019). The model assumed, a flat-layered poro-elasticity deformation in the formation rock, couple of certain constant strains $\varepsilon S H m a x$ and $\varepsilon S H m i n$ which applied to the formation of the minimum and maximum horizontal stress direction. The Poro-Elastic Horizontal Strain Model can be described by using static Young's modulus, static Poisson's ratio, overburden stress, and pore pressure that calculated by utilized Eaton slowness, and Biot's constant $(\alpha=1)$ (Schlumberger, 2015). For a fluid which saturated the porous material is supposed to be isotropic with linear elastic and anisotropic tectonic strain to evaluate the magnitude of the maximum and minimum horizontal stresses as formulated in the equation (9) and (10), respectively (Schlumberger, 2015).

$$
\begin{aligned}
& \sigma \mathrm{H}=\frac{V}{1-V} \sigma \mathrm{V}-\frac{V}{1-V} \alpha \mathrm{Pp}+\alpha \mathrm{Pp}+\frac{E}{1-V^{2}} \varepsilon \mathrm{H}+\frac{V E}{1-V^{2}} \varepsilon \mathrm{h} \\
& \sigma \mathrm{h}=\frac{V}{1-V} \sigma \mathrm{v}-\frac{V}{1-V} \alpha \mathrm{Pp}+\alpha \mathrm{Pp}+\frac{E}{1-V^{2}} \varepsilon \mathrm{h}+\frac{V E}{1-V^{2}} \varepsilon \mathrm{H}
\end{aligned}
$$


Where:

$\sigma \mathrm{H}$ and $\sigma \mathrm{h}$ : maximum and minimum horizontal stresses (psi).

$\sigma \mathrm{v}$ : overburden stress (psi).

V: Poisson's ratio (unitless).

$\alpha$ : Biot's coefficient (conventionally $\alpha=1$ ).

E: static Young's modulus (Mpsi).

Pp: pore pressure (psi).

$\varepsilon \mathrm{H}$ and $\varepsilon$ : maximum and minimum principle horizontal strain.

The analysis of the state of stress revealed that the stress regime in the Zubair Formation is normal faulting (Sv > SHmax $>$ Shmin) according to Anderson's theory and its agreement with Abbas study (2018) about the development of geomechanical model in Zubair Formation in South Iraq. The deviation from normal regime to strike-slip faulting regime (SHmax $>\mathrm{Sv}>\mathrm{Shmin}$ ) in some intervals that may attributed to faults existence by depended on the geological report. It refers to find a fault system naturally diffused throughout Zubair strata in Rumaila field. Formation micro-image log (FMI) is the common technique which used for determining the orientation of the horizontal principle stresses by predicting shear and tensile failure. The result of the interpreted image log revealed that, the breakout direction $\left(140^{\circ}-150^{\circ}\right)(\mathrm{NW}-\mathrm{SE})$ and that represent to Shmin direction as shown in Fig.4 (Abbas et al., 2019). Whereas, the direction of the maximum horizontal stress is perpendicular to the minimum horizontal stress and range between $40^{\circ}-60^{\circ} \mathrm{NE}-\mathrm{SW}$, the construction of geomechanical model has been performed by estimating the vertical stress, formation pore pressure, rock mechanical properties (elastic and strength), and the magnitude of in-situ horizontal stress as shown in Fig.5.

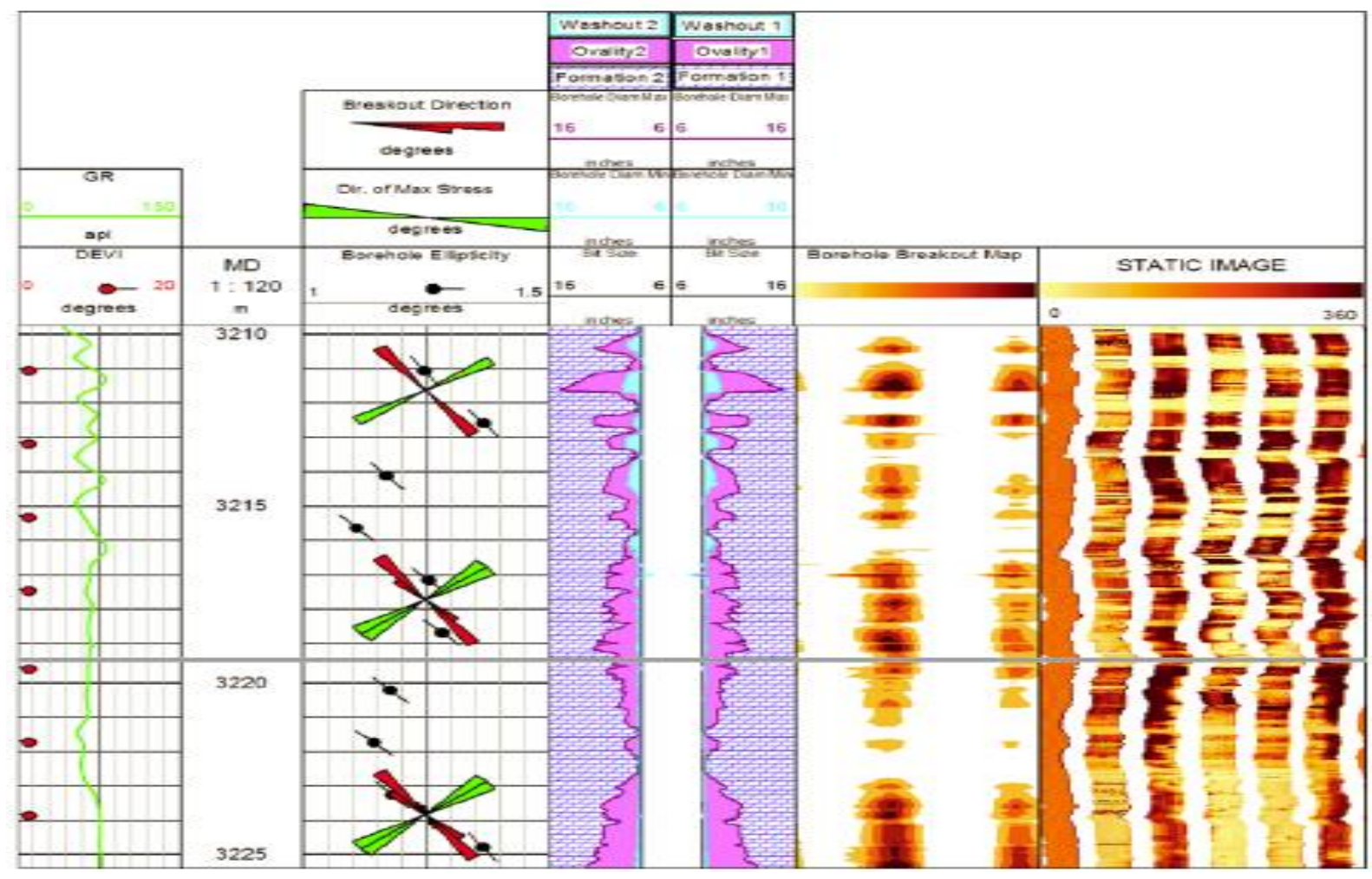

Fig. 4. Interpreted micro-image log (Abbas et al., 2019) 


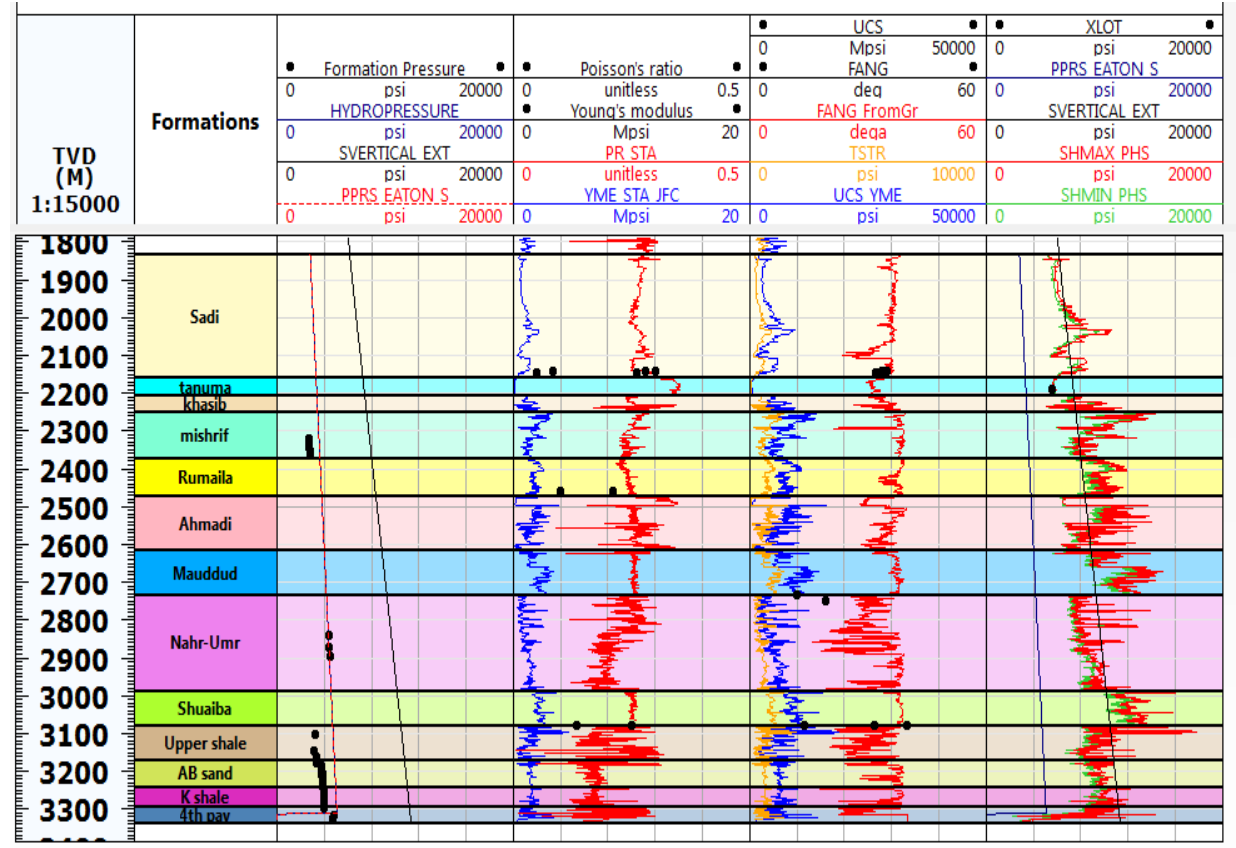

Fig. 5. Final elements of mechanical earth model (1-D-MEM)

\section{Results and Discussions}

\subsection{Geomechanical Model Validation}

Each building process of geomechanical model needs to validated with the actual field data in order to evaluation the model accuracy and to accredit the results in the future well design and in field planned development. The validation process is considered as critical step during the history matching and should be implemented before of the model application. To identify the failure of the borehole, there are several techniques that can be used for this purpose such as caliper log (4-arms or 6-arms), formation micro-image log (FMI), and from cuttings. It is worth to mention that, angular cuttings are the first indicator of the shear failure because it is observed in screens of shale-shaker while drilling process (Zhang, 2019). Fig.6 to Fig.8 illustrated the wellbore failure which was predicted by the failure criteria (i.e. Mohr-Coulomb, Mogi-Coulomb, and Modified Lade) criterion. These figures characterize the pore pressure, rock properties, predicted mud weight window, rock failure, and actual profile of the well. In each figure, track 4 describes the mud weight window that including of pore pressure, breakdown, losses, and shear failure with different colors as presented below in Table 1:

Table 1. The mud weight window limits.

\begin{tabular}{ll}
\hline Family name & \multicolumn{1}{c}{ Description } \\
\hline Pore pressure & $\begin{array}{l}\text { Defines the limit of the minimum mud weight needed to maintain hydraulic } \\
\text { safety. } \\
\text { Defines the maximum mud weight allowed for mechanical stability of the } \\
\text { borehole. }\end{array}$ \\
Losses & $\begin{array}{l}\text { When the well mud weight pressure equals to the minimum horizontal stress } \\
\text { that cause losses of the mud weight to the fracture formations. }\end{array}$ \\
& $\begin{array}{l}\text { Below this mud weight the rock start to fail, thus intensive breakout occurs } \\
\text { and Defines the minimum mud weight allowed for mechanical stability of } \\
\text { the borehole. }\end{array}$ \\
\hline
\end{tabular}


On the left side of track 4 and to prevent occurrence of the kick and or rock failure, the actual mud weight must be greater than the pore pressure (guide to kick) and shear failure (display the limit of the mud weight corresponding to shear failure). while, on the right side the light blue trend detects the limit of the mud weight which acts as the minimum horizontal stress, whereas the dark blue trend shows the limit of mud losses or represent the mud begin to penetrate the formation. To prevent the mud losses and breakdown failure, the actual mud weight should be lower than the breakdown and losses profile. Thus, for safe drilling operations and stable wellbore the optimum mud weight should be kept in the middle area between the boundaries of breakout and fracture gradient and this known as safe mud weight window (MWW). Track 5 explains the predicted profile of the rock failure based on the failure criteria which utilized in the study. The predicted failure varied between green-colored shallow Knockouts and red-colored wide breakouts.

The actual profile of the well was recorded and represented by the caliper log and bit size as presented in track 6. Caliper log is a well logging tool which supplies of shape and size of the borehole measurements along the well depth and utilizing to compare with the predicted profile for completing the validation process of the geomechanical model. Through analysis the predicted wellbore instability with actual profile of the failure of the rocks, the observation shows there are no agreement between the actual and predicted profiles when utilized Mohr-Coulomb criteria that may be return to ignoring the intermediate stress (Zoback, 2007). Good matching show when utilized Modified-Lade Criteria but it is more conservative to shear failure. Whereas, Mogi-Coulomb criteria show a closer agreement to the real profile of the wellbore that observed from caliper log for Rumaila oilfield.

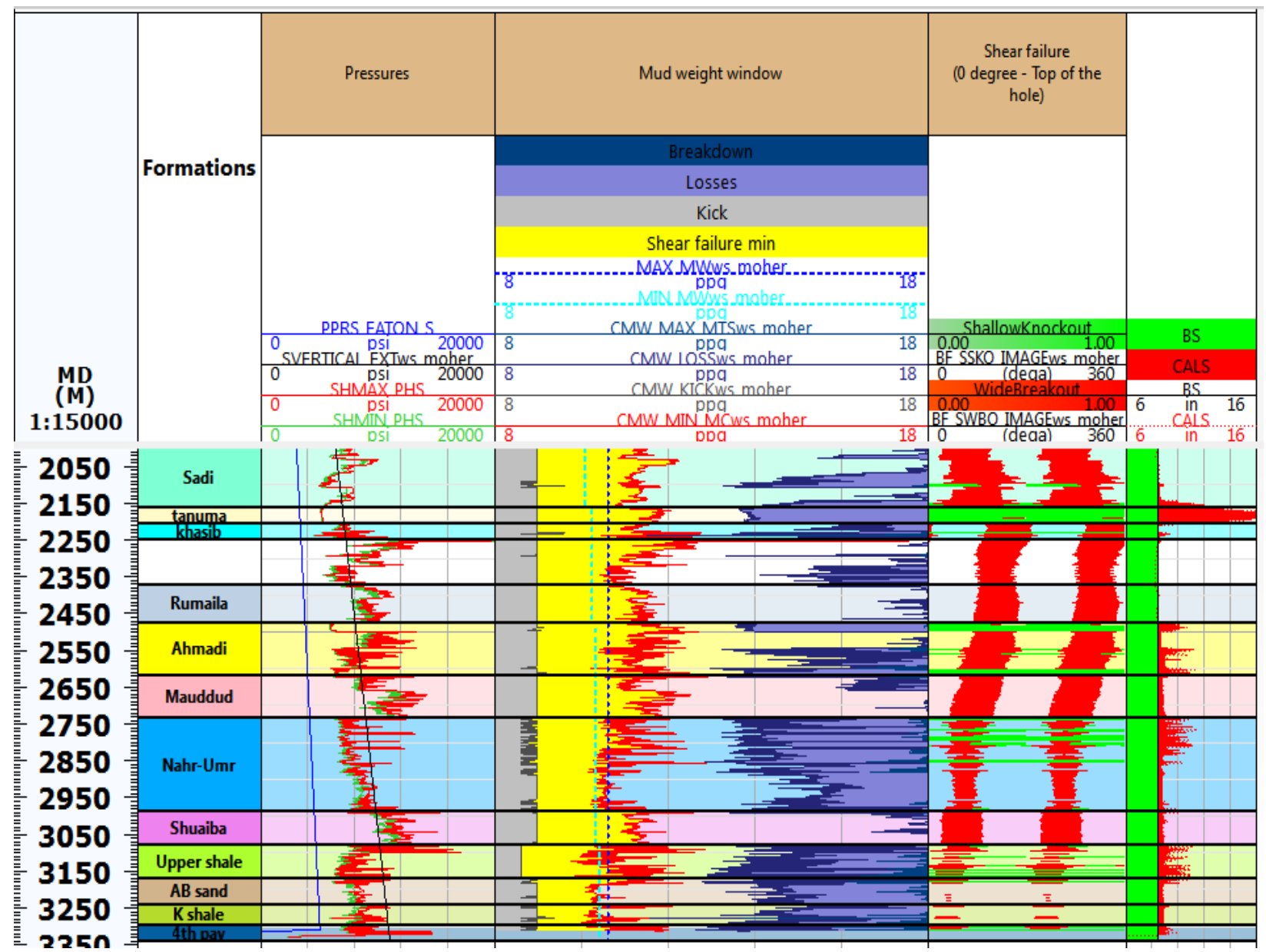

Fig. 6. Wellbore failure predicted by Mohr-Coulomb failure criterion 


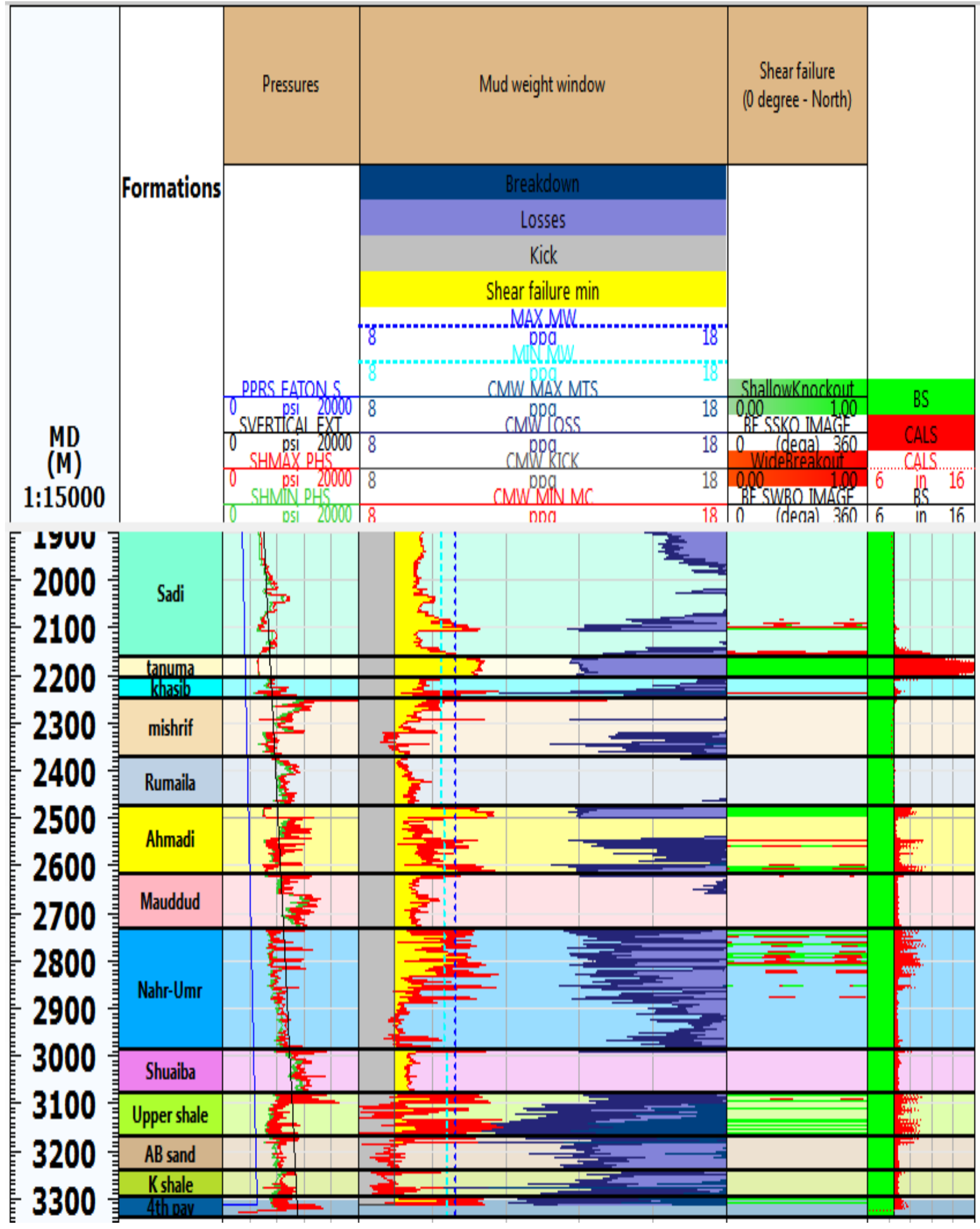

Fig.7. Wellbore failure predicted by Mogi-Coulomb failure criterion 


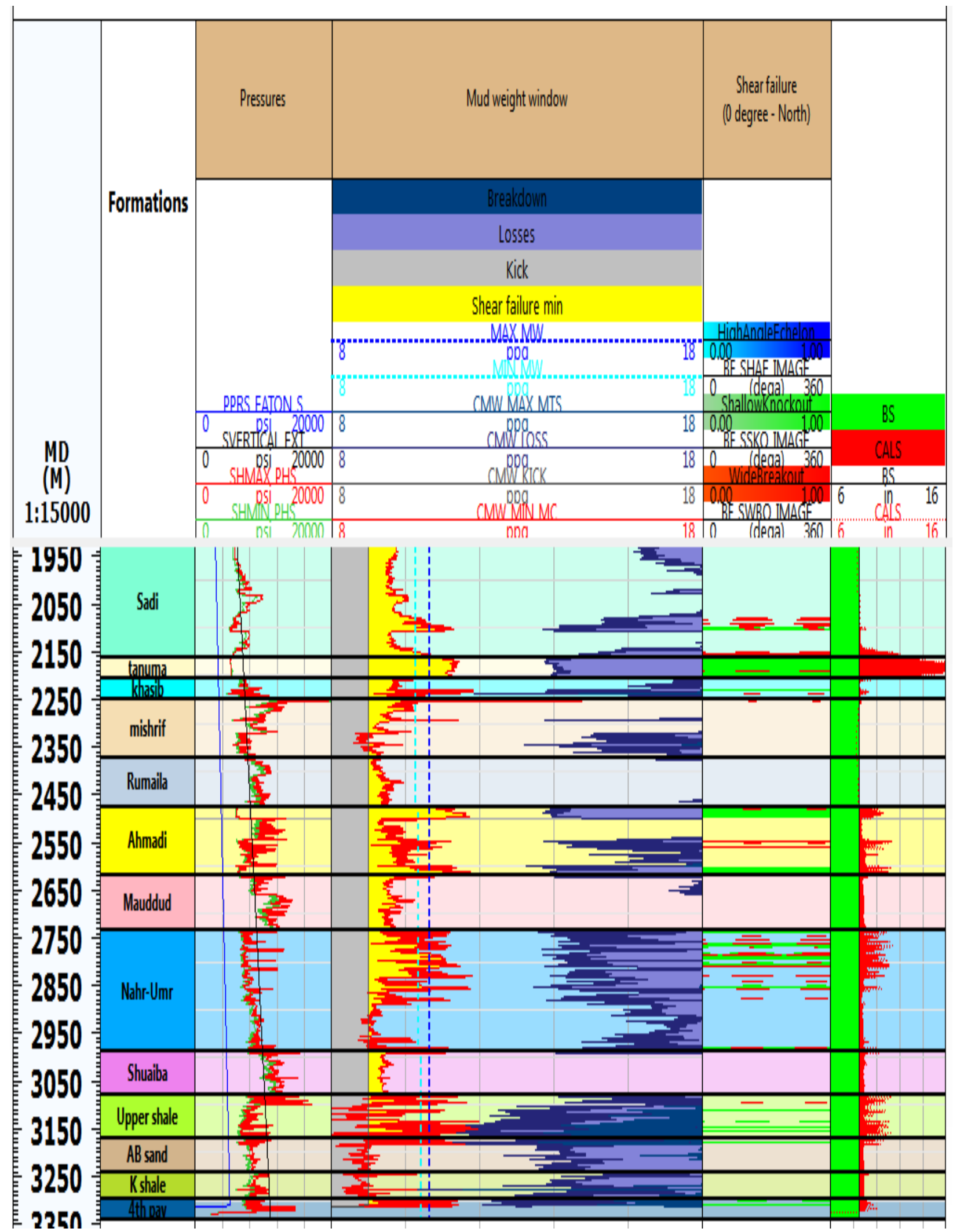

Fig. 8. Wellbore failure predicted by Modified-Lade failure criterion 


\subsection{Sensitivity Analysis}

The prevalent method to evaluate the sensitivity analysis of the borehole stability to the path of drill is the hemisphere. The hemisphere plot is a circle gridding from $\left(0^{\circ}-360^{\circ}\right)$ and used to identified the azimuth and inclination of the wellbore. Borehole information needed to performed the sensitivity analysis at single depth which include well orientation, geomechanical model parameter, and the mud weight window. The sensitivity analysis introduces four diagrams as following:

The first relation of the breakout mud weight with the orientation, noticeable dark blue color refers to more stable wells with deviated angle between $\left(0^{\circ}-40^{\circ}\right)$. While, the red color represents the more deviated and horizontal wells and revealed a higher value of the mud weight to keeping the stability of the wellbore as shown in Fig.9 (Schlumberger, 2015). For second relation of tensile failure versus orientation it explains the higher limit of breakdown mud weight in the minimum horizontal stress orientation. Whereas, the horizontal or highly deviated wells that oriented to the maximum horizontal stress shows the lower limit of mud weight as shown in Fig.10 (Schlumberger, 2015). Because of sandstone more brittle and apt to fractured, the induced-tensile failure and mud losses are easily to occur in sandstone. while, shale more probable for developing the breakout comparing with the sandstone (Zhang, 2019).bThe sensitivity analysis of mud weight window revealed the safe mud weight below $30^{\circ}$. Whereas, the azimuth has no impact on the mud weight as illustrated in Fig.11and Fig.12.

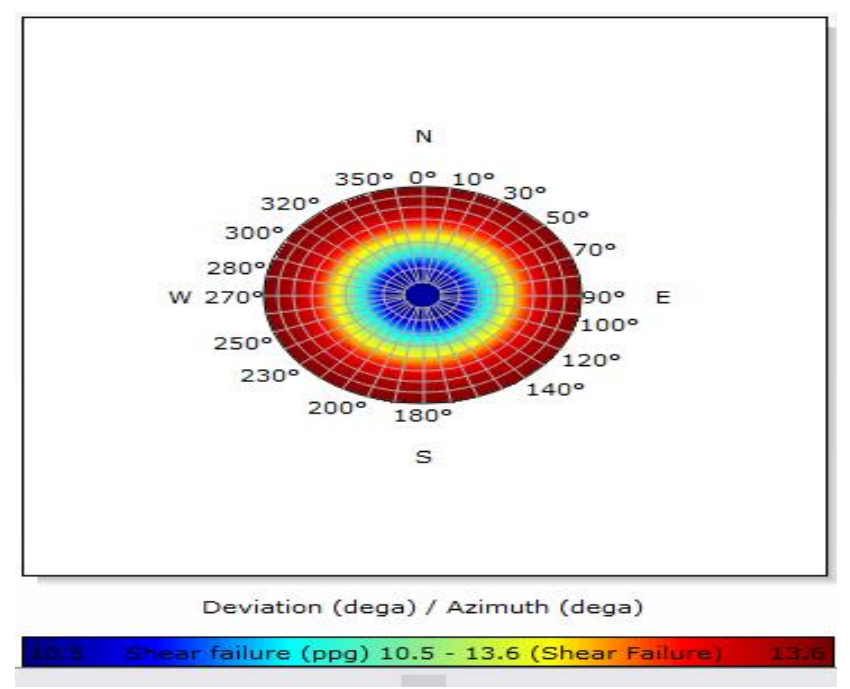

Fig. 9. Breakout mud weight vs orientation

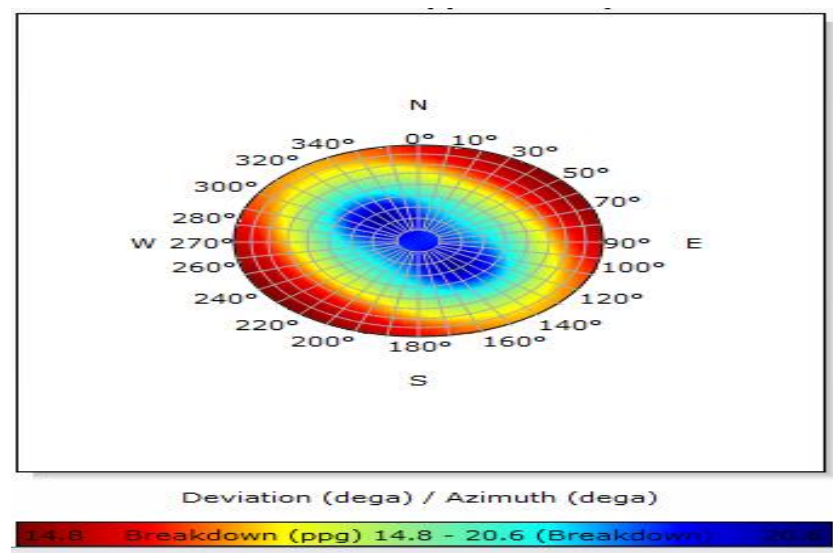

Fig. 10. Breakdown mud weight vs orientation 


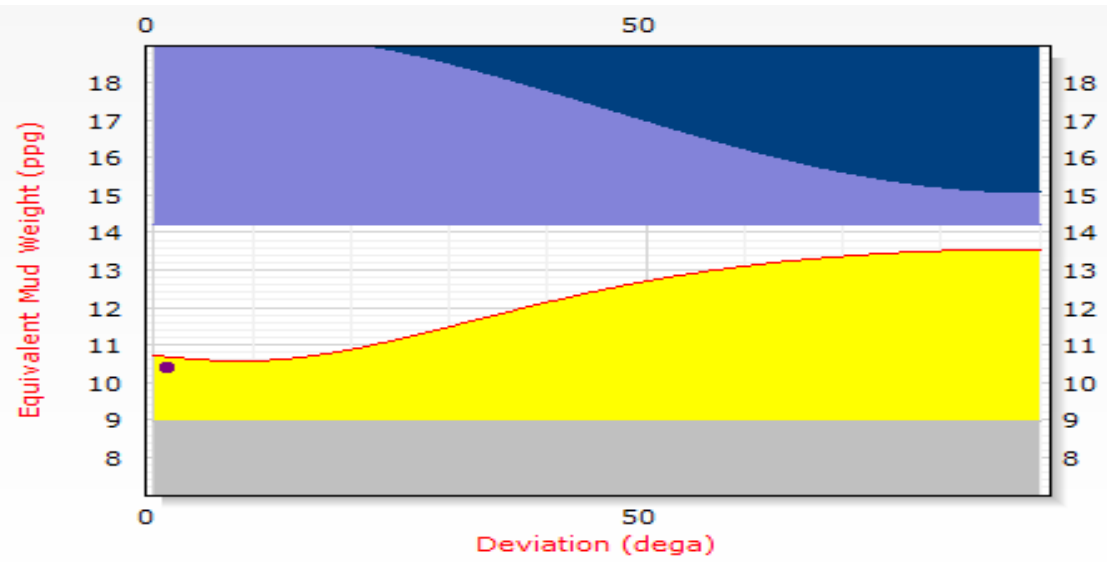

Fig. 11. Mud weight window vs deviation

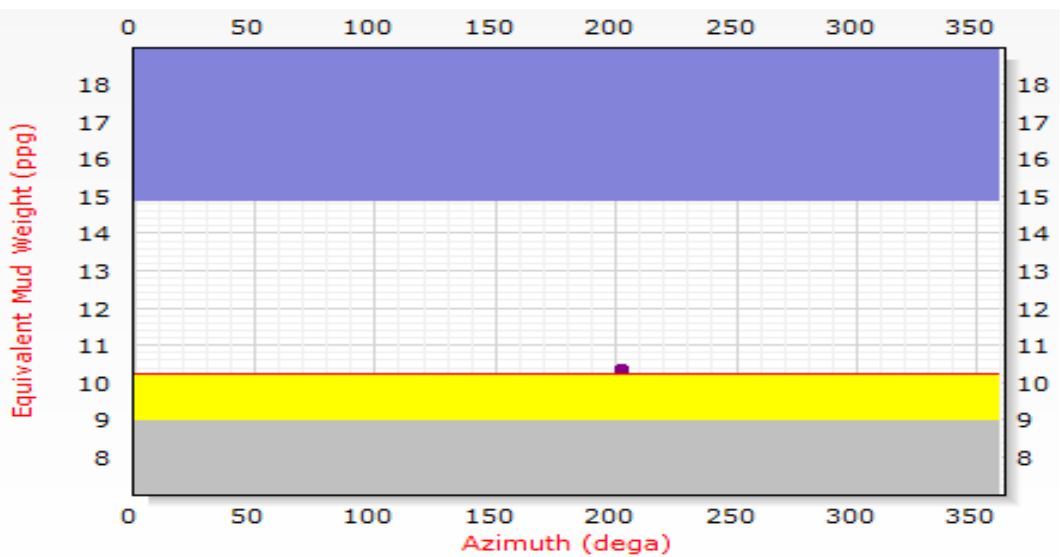

Fig. 12. Mud weight window vs Azimuth.

\section{Conclusions}

In each study and analysis of geomechanical, it is essential to knowing of the rock mechanical properties and the magnitude of the stresses. In this work, implement a mechanical earth model based on available data for vertical wells from Rumaila oilfield/South of Iraq. The study showed Mogicoulomb is better failure criteria utilized to validating the geomechanical model and was chosen as the more suitable failure criteria for prediction of the failure in the Rumaila oilfield and analysis of the wellbore instability. The investigation of this study revealed the tectonic stress regime is predominated by normal stress regime $(\mathrm{Sv}>\mathrm{SHmax}>\mathrm{Shmin})$. The sensitivity analysis showed vertical and low deviated wells is more stable than the highly deviated and horizontal wells and the mud weight which used is insufficient and should be increased to $10.5 \mathrm{ppg}$ to maintain the wellbore wall is stable during the drilling operations. These results can be invested to reduce the high NPT and over cost of well during the drilling practice.

\section{Acknowledgements}

The author is very grateful to the Editor in Chief Prof. Dr. Salih M. Awadh, the secretary of Journal Mr. Samir R. Hijab and the Technical Editors for their great efforts and valuable comments. 


\section{References}

Aadnoy, B. and Looyeh, R., 2011. Petroleum rock mechanics: drilling operations and well design. Gulf Professional Publishing.

Abbas, A.K., Al-Asadi, Y.M., Alsaba, M., Flori, R.E. and Alhussainy, S., 2018. Development of a geomechanical model for drilling deviated wells through the Zubair formation in Southern Iraq. In SPE/IADC-189306MS. Middle east drilling technology conference and exhibition. OnePetro

Abbas, A.K., Alhussainy, S.D., Abdul Hussien, H.A. and Flori, R.E., 2019. Safe mud weight window determination: A case study from Southern Iraq. The American Rocks Mechanics Association, 19-241.

Al-Jafar, M. K., Al-Jaberi, M. H., 2019. Well logging and electrofacies of Zubair Formation for Upper Sandstone Member in Zubair Oil Field, Southern Iraq. The Iraqi Geological Journal, 52, (1)101-124.

Al-Mimar, H.S., Awadh, S.M., Al-Yaseri, A.A. and Yaseen, Z.M., 2018. Sedimentary units-layering system and depositional model of the carbonate Mishrif reservoir in Rumaila oilfield, Southern Iraq. Modeling Earth Systems and Environment, 4(4), 1449-1465.

Albukhari, T.M., Beshish, G.K., Abouzbeda, M.M. and Madi, A., 2018. Geomechanical wellbore stability analysis for the reservoir section in JNC186 oil field. In ISRM 1st International Conference on Advances in Rock Mechanics-TuniRock 2018. OnePetro.

Alsultan, H.A., Awadh, S.M., Al-Owaidi, M.R. and Al-Khafaji, A.J., 2021. Sequence Stratigraphy and Depositional Environment of the Zubair Formation in Rumaila Oilfields, Southern Iraq: Microfacies and Geochemistry. The Iraqi Geological Journal, 28-41.

Awadh, S.M., Al-Mimar, H.S. and Al-Yaseri, A.A., 2018. Salinity mapping model and brine chemistry of Mishrif reservoir in Basrah oilfields, Southern Iraq. Arabian Journal of Geosciences, 11(18), 1-12.

Awadh, S.M., Al-Mimar, H.S. and Yaseen, Z.M., 2021. Effect of Water Flooding on Oil Reservoir Permeability: Saturation Index Prediction Model for Giant Oil Reservoirs, Southern Iraq. Natural Resources Research, 113.

Aziz, Q. A. A., Hussein, H. A., 2021. Mechanical rock properties estimation for carbonate reservoir using laboratory measurement: A case study from Jeribe, Khasib and Mishrif Formations in Fauqi Oil Field. The Iraqi Geological Journal, 54 (1E), 88-102.

Bjorlykke, K., 2010. Petroleum geoscience: From sedimentary environments to rock physics. Springer Science \& Business Media.

Fjaer, E., Holt, R.M., Horsrud, P., Raaen, A.M. and Risnes, R., 2008. Geological aspects of petroleum related rock mechanics. Developments in petroleum science, 53, pp.103-133.

Haimson, B.,Chang, C., 2000. A new true triaxial cell for testing mechanical properties of rock, and its use to determine rock strength and deformability of Westerly granite. International Journal of Rock Mechanics and Mining Sciences, 37(1-2), 285-296.

Najibi, A.R., Ghafoori, M., Lashkaripour, G.R. and Asef, M.R., 2017. Reservoir geomechanical modeling: In-situ stress, pore pressure, and mud design. Journal of Petroleum Science and Engineering, 151, .31-39.

Rasouli, V., Pallikathekathil, Z.J. and Mawuli, E., 2011. The influence of perturbed stresses near faults on drilling strategy: a case study in Blacktip field, North Australia. Journal of Petroleum Science and Engineering, 76(1-2), 37-50.

Rumaila Operating Organization, ROO. 2016. Integrated Subsurface Description (unpublished report).

Schlumberger, 2015. Techlog Pore Pressure Prediction and Wellbore Stability Analysis Workflow, Solutions Training.

Zhang, J., 2013. Borehole stability analysis accounting for anisotropies in drilling to weak bedding planes. International Journal of Rock Mechanics and Mining Sciences, 60, 160-170.

Zhang, J.J., 2019. Applied Petroleum Geomechanics. Gulf Professional Publishing.

Zoback, M.D., 2007. Reservoir geomechanics: Earth stress and rock mechanics applied to exploration. Production and wellbore stability, 449. 